\title{
Indkørslen til Charlottenlund ca. 1830
}

af prokurist Erik Housted

Erik Housted er forfatter af flere bøger og artikler af lokalhistorisk indhold (Fredericia og København). Igangvarende arbejde om H.G.F. Holm og hans arbejder forventes udsendt $i$ efteråret 1992.

I foråret 1991 erhvervede Billedafdelingen gennem Arnold Buscks Antikvariat et af H.G.F. Holms små yndefulde prospekter med titlen Indkjørslen til Charlottenlund.

Nyerhvervelsen supplerer på fortrinlig vis den række af H.G.F. Holms arbejder som i forvejen er i afdelingens besiddelse, herunder bl.a. et tidligt arbejde af Holm med Teltene $i$ Charlottenlund.

Motivet er på sin vis enestående, idet der - forfatteren bekendt - ikke kendes andre prospekter som viser netop dette motiv, hverken af Holm eller andre kunstnere, og det har derfor en betydelig topografisk værdi.

På kun 104 x $142 \mathrm{~mm}$ har Holm i blyant og sepialavering formået med sin vanlige akkuratesse at illustrere, hvorfor Charlottenlund i første halvdel af forrige århundrede var københavnernes foretrukne udflugtsmål. Den enestående udsigt over Svanemøllebugten mod København, hvis profil med de velkendte tårne åbenbarer sig for beskueren, er forlængst gået tabt. Anlæggelsen af Tuborg havn og fabrikker i 1870'erne og opførelsen af Charlottenlundfortet fra 1886 og senere tiders tiltagende bebyggelse har gjort, at stedet idag næppe kan genkendes.

J. Plenge fortæller i Nogle Trak af Livet i Kjфbenhavn for en Menneskealder siden, udg. 1877: "Ved "Skoven" forstod man i hine Tider egentlig kun Charlottenlund, der er det oprindelige Valfartssted for de frisk-Luftsøgende Kjøbenhavnere. Hertil kunne man dengang, da Fødderne endnu ikke vare så ømme, let gaa, og store vare de Skarer, der navnlig om Søndagen fyldte den langs med Strandvejen løbende brede Fodsti, der ofte om Aftenen gjenlød af glade Menneskers Sang." 
En anden forfatter, litteraten H.F. Martensen, beretter i Conversationsbladet (5. august 1826) : "Charlottenlund er kun en liden Skov, men rig på skjønne Partier, hvorfor den ogsaa allerede tidligt i dens Opvæxt var et Yndlingssted for Hovedstadens Indvaanere. Om Morgenen tidligt er der især overordentlig skjønt i Skoven; en utallig Mængde Fugle qvidre saa yndigt deres Morgensang; Træerne nedvifte den friskeste Vind; Raabukkene springe saa muntert over engene; kun en enkelt Vandrer seer man trave igjennem Skoven, ellers er Alt roligt og stille; det er da et yndigt Opholdssted; længere op ad Dagen, naar Stadens stive Straajunkere og deres sippenippede Kneisnakker ankomme, da er man geneert i hver en Gang. Det smukkeste Parti af Skoven er noget nær det bag Slottet, ud af Markerne til; naar man fra Skovhuset ved Jægersborg-Alleen følger i udkanten af Skoven langs Gjærdet og kommer ud ved Staldene oppe ved Holdepladsen, da har man gjort en vakker Tour; ved Teltene og den Vei som løber langs med Gjærdet ved Grøndahls Skovhuus ved Dyrehaugsveien, har man paa de smaa Høie skjønne udsigter til Kjøbenhavn og ud i Sundet. Paa den anden side af Veien, som gaaer til Dyrehaugen, er der skjønnest i Granpartiet og nede i Dalen ved Humlehaugen."

Det er netop dette sidste parti Holm har tegnet. Bag stakittet løber den sandede og støvede Strandvej. Vejen var netop i årene før Holm udførte sin tegning blevet istandsat på strækningen mellem "Slukefter" og Klampenborg, og ved samme lejlighed blev der anlagt en stor halvkredsformet holdeplads som kunne rumme henved 400 vogne. Pladsen anes netop på Strandvejens vandside udfor lågen, hvor vognen med skovgæster er på vej ind ad vore dages Jægersborg allé, som dengang, på strækningen gennem skoven, kun var en smal grusvej.

Fortsatte man lidt længere frem ad vejen, kom man til "Teltene", betegnelsen for de 6-8 beværtnings- og forlystelsestelte som blev slået op her hele sommeren og som frem for noget var målet for skovgæsternes vederkvægelser. Her var sang og musik, her kunne man slukke tørsten og stille appetitten og man kunne nyde de enkle forlysteiser som aldrig forfaldt ned på det grovere plan som kendetegnede Dyrehavsbakken.

Sæsonen i Charlottenlund varede hele sommeren i modsætning til Dyrehavsbakken, hvor fornøjelserne var indskrænket til tre uger. Kl. 11 aften forkyndte slag på en ophængt klokke, at nu var det tid at lukke og en strøm af glade, opstemte mennesker vældede tilbage mod staden til fods, til hest og til vogns.

Her lå også etablissementet "Over Stalden", hvis historie gik tilbage til 1823, hvor tidligere løjtnant ved Husarregimentet Frederik Joachim v. Wiglar fik kongelig tilladelse til at opføre et træskur til opstaldning af skovgæs- 


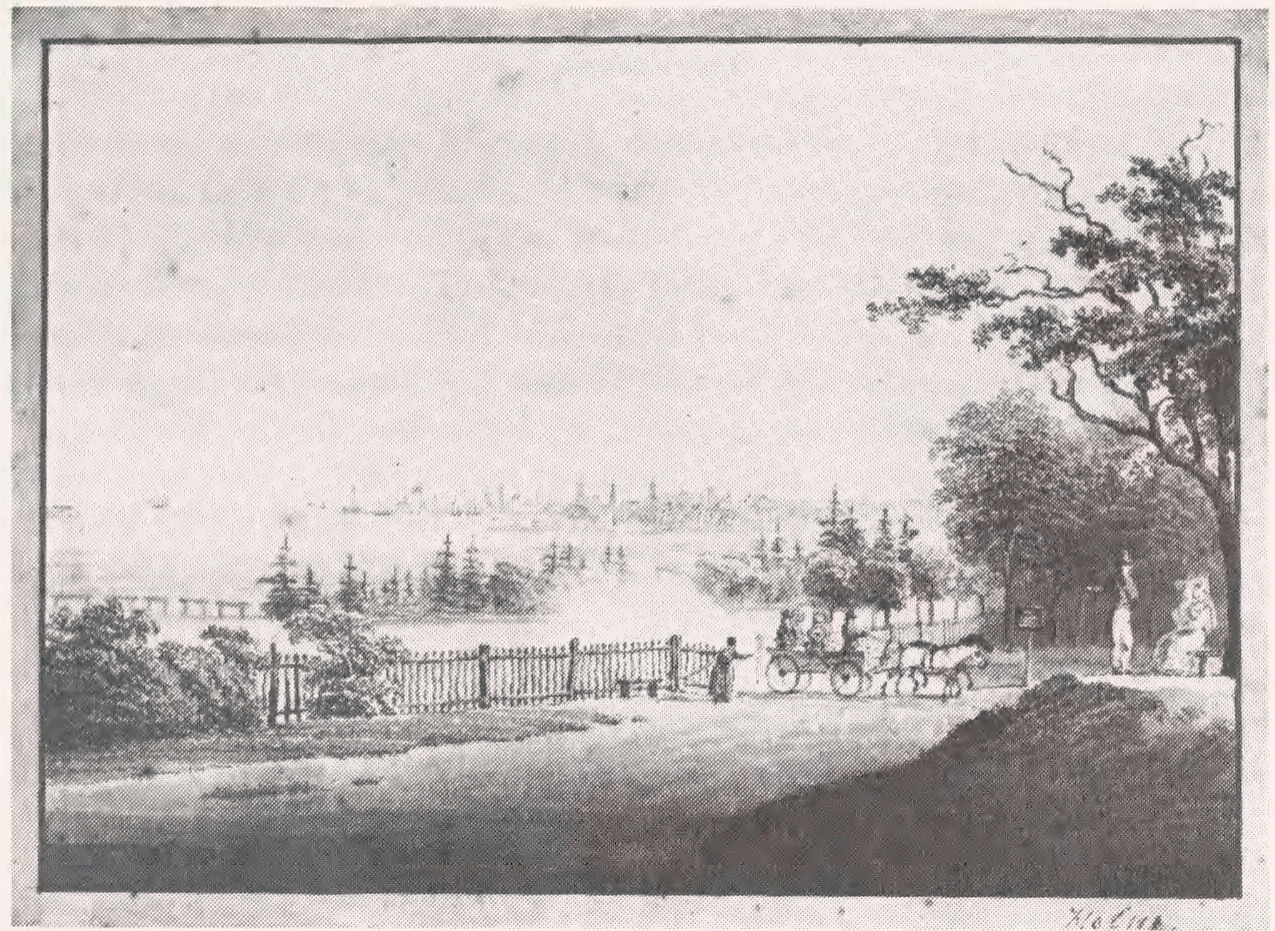

Indkjørslen til Charlottenlund. H.G.F. Holm. Nyerhvervet til Kort- og Billedafdelingen.

ternes heste. Ni år senere udvidede Wiglar forretningen. Bræddeskuret blev afløst af en staldbygning i mur og bindingsværk. I tagetagen blev indrettet værelser til udlejning og her blev indrettet restaurant og cafe med udgang til en baldakinoverdækket terasse foran gavlen. Forskellen blev straks slået an: etablissementet var bestemt "for den bedre del af Publikum, der ikke $\emptyset$ nske at besøge Teltene".

Her residerede schweizerkonditor Lardellis enke med sine harpespillersker og sangerinder, for Wiglar desværre med det resultat, at hun tog løvens part af etablissementets betydelige indtægter, medens han sank ned i dybere og dybere gæld, så staten i 1839 måtte overtage bygningerne. Wiglar fik dem dog til leje til sin død i 1846.

H.G.F. Holm udførte flere prospekter fra Charlottenlund: slottet, teltene og Wiglars etablissement og da flere af dem er udført i adskillige eksemplarer, er det sandsynligt at Holm jævnligt har færdedes blandt skovgæsterne og har falbudt sine produkter, for hvilke han sædvanligvis fik 1 à 2 Rdl.

Proveniensen af det netop erhvervede billede kendes ikke. Formentlig er det det, som i marts 1935 blev solgt fra greve Theodor Ahlefeldt-Laurvigs bo på Chr. Hee's Eftf. auktioner under katalog nr. 46, hvor det betitledes: "Indkørslen til Charlottenlund. Fru Heibergs Høj ses på billedet. Tegning se- 
pia" Senere har det så vidt vides været i en lang årrække hos en dansk familie på de Vestindiske øer.

Fru Heibergs Høj, et navn som ellers ikke er overleveret, må være højen i billedets forgrund, en af de tre små bronzealderhøje som endnu idag ligger foran og ved siden af Skovriderkroen. Forklaringen finder vi måske i J.L. Heibergs Dyrehavsreisen, som rummer reminiscenser fra sværmeriske ture med den lille Johanne Luise Pätges, der skulle forgylde hans hjem som hustru fra 1831 og skabe Det kgl. Teaters store ry bl.a. under sin husbonds ulykkelige lederperiode 1849-56:

Vær hilset, skjønne

Charlottenlund!

Du skjermer os mod Solens Pile.

Ved blanken Sund,

Vi vandre vil tilfods, og hvile.

En Høi sig hvælver over Kæmpens Been;

$\mathrm{Nu}$ staae vi paa dens mosbegroede Steen.

Ak, du er død!

Mig Livets Glød

End varmer mildt, hvor Piger smile!

Jeg ret jer takker,

I kjære Smaa!

Ved eders Hjelp den Bænk er funden, hvori saa vakker

Staaer L og H,

Og som jeg troede længst forsvunden.

Engang da Verden gik mig haardt imod,

Jeg her det ristede ved Bøgens Rod.

Nu Glæden blid

Mig fører did

Ved sine Genier i Lunden.

Såvidt Heibergs, som også senere i tilværelsen var hyppige gæster i Charlottenlund. Med forkærlighed har de opsøgt bænken (på højen?) med de indristede initialer.

Prospektets skaber, Heinrich Gustav Ferdinand Holm, var født i Berlin den 23. april 1803. 
Hans far, maler og kobberstikker Jens Holm, stammede fra København, født i 1776 som søn af en brændevinsbrænder i Rosengården. I henved en snes år arbejdede han som maler, lakerer og kobberstikker for den herrnhutiske lakvarefabrikant Johann Heinrich Stobwasser på dennes manufaktur i Wilhelmstrasse. Her blev fremstillet allehånde former for lakerede varer, men fortrinsvis snustobaksdåser i papmache, forsynede med miniature-malerier af meget høj karat.

Det er utvivlsomt her grunden blev lagt til det som senere blev såvel Jens som H.G.F. Holms speciale: vendutemaleriet, den topografisk korrekte gengivelse af et bybillede eller landskab. Netop sådanne prospekter indgik i rigt mål i Stobwassers produktion og Jens Holm har desuden været fuldt fortrolig med stilen fra Berliner-malere som f.eks. Johann Georg Rosenberg og Fridrich August Calau, hvis arbejder næsten til forveksling minder om Holms tidligere arbejder fra København.

Jens Holm giftede sig i 1802 i Berlin med en datter af en artilleriunderofficer og deres første barn, H.G.F. Holm (opkaldt efter en af Stobwassers sønner) blev født året efter. Yderligere to børn døde som spæde.

I 1816 døde Jens Holms moder i København (faderen var død allerede i 1800) og da hun efterlod sig en pæn lille formue, brød familien op fra Berlin og var fra efteråret 1816 bosat i København.

Her oplærte Jens Holm sønnen i kobberstikning og perspektivtegning.

Hans tidligste daterede arbejder stammer fra 1819. De virker endnu lidt umodne og specielt har perspektivet voldt problemer, men i løbet af få år opnåede han, takket være et tæt samarbejde med faderen, en på sin vis enestående færdighed. Far og søn udgav sammen bl.a. nogle kobberstukne serier Prospecter af Kiфbenhavn efterfulgt i 1825-27 af den meget smukke kobberstukne prospektserie Sjallands yndigste Egne, hvor en del af oplaget var håndkoloreret ved udgivelsen.

Selv om H.G.F. Holm var en særdeles habil kobberstikker - og faktisk mest virkede som sådan i sine helt unge år - er det især fra hans talrige prospekter fra København og omegn, udført i tegning eller akvarel, vi kender ham.

Han nød en vis bevågenhed fra bl.a. C.W. Eckersberg, som havde et godt $\varnothing j$ je for hans talent, men især synes han at være blevet påskønnet af en række af tidens arkitekter som f.eks. G.F. Hetsch, Christian Hornbech og Jørgen Hansen Koch.

Trods en tilsyneladende god og relativt ubekymret start på tilværelsen, vendte billedet hen mod slutningen af 1820 'erne. Familieformuen "forsvandt" under dunkle omstændigheder og såvel far som søn sank ned i stadig dybere armod, der allerede dengang skaffede H.G.F. Holm tilnavnet "Fattig-Holm". 
Man har været tilbøjelig til at se ham som en forhutlet og fordrukken person, men $\mathrm{i}$ alt fald det sidste holder ikke stik. Forklaringen på hans trange kår og triste livsskæbne skal snarere søges i sjælelige lidelser. Holms mor blev sindssyg, det samme gjorde tre af hans børn og karakteristisk nok dukker sygdommen op i 30-års alderen. H.G.F. Holm selv er formentlig også - netop i denne alder - blevet ramt af periodiske depressioner.

En antydning heraf får man bl.a. i C.F. Wilkens erindringer om Thorvaldsen, som iøvrigt støttede Holm og beundrede hans arbejder. Wilkens siger (i 1840): "Holm hørte allerede dengang til de mennesker, som er tabte for samfundet".

Holm døde 1. maj 1861 på Almindeligt Hospital i Amaliegade, men ikke som fattiglem, som det ofte er blevet udlagt.

Dødsårsagen var tuberkulose, et resultat af mange års ophold i hastigt skiftende boliger af ringe karat, fortrinsvis i kvarteret omkring Adelgade/ Borgergade.

Kun få i samtiden havde virkelig øje for hans talent og han fik kun ringe betaling for sine arbejder. Idag er de eftertragtede og betales oftest til høje priser, når de lejlighedsvis dukker op ved kunstauktionerne og $i$ handelen.

Om hans arbejder er kunst eller ej kan man diskutere, men det kan i alt fald slås fast, at Holm er en af de bedste og mest produktive kilder til vor viden om Københavns og omegnens topografi i tiden op mod voldenes fald. 